Article

\title{
Is Empowerment of Female Radiologists Still Needed? Findings of a Systematic Review
}

\author{
Giulia Fichera ${ }^{1,+}\left(\mathbb{C}\right.$, Isolde Martina Busch ${ }^{2,+}+$, , Michela Rimondini ${ }^{2}$, Raffaella Motta $^{1}$ and Chiara Giraudo ${ }^{1, *(1)}$ \\ 1 Department of Medicine-DIMED, Institute of Radiology, University of Padova, 35122 Padova, Italy; \\ gfichera90@gmail.com (G.F.); raffaella.motta@unipd.it (R.M.) \\ 2 Section of Clinical Psychology, Department of Neuroscience, Biomedicine and Movement Sciences, University \\ of Verona, 37134 Verona, Italy; isoldemartina.busch@univr.it (I.M.B.); michela.rimondini@univr.it (M.R.) \\ * Correspondence: chiara.giraudo@unipd.it; Tel.: +39-049-8212357 \\ + These authors equally contributed and should be considered as co-first authors.
}

check for updates

Citation: Fichera, G.; Busch, I.M.; Rimondini, M.; Motta, R.; Giraudo, C. Is Empowerment of Female Radiologists Still Needed? Findings of a Systematic Review. Int. J. Environ. Res. Public Health 2021, 18, 1542. https://doi.org/10.3390/ijerph1804 1542

Academic Editor: Stuart Gilmour

Received: 22 December 2020

Accepted: 2 February 2021

Published: 5 February 2021

Publisher's Note: MDPI stays neutral with regard to jurisdictional claims in published maps and institutional affiliations.

Copyright: (c) 2021 by the authors. Licensee MDPI, Basel, Switzerland. This article is an open access article distributed under the terms and conditions of the Creative Commons Attribution (CC BY) license (https:// creativecommons.org/licenses/by/ $4.0 /)$.

\begin{abstract}
Considering that radiology is still a male-dominated specialty in which men make up more than two thirds of the workforce, this systematic review aimed to provide a comprehensive overview of the current role of women in radiological imaging, focusing on the main aspects such as career progression, leadership, academic practice, and perceived discrimination. Three electronic databases were searched up to 21 October 2020. To identify additional records, weekly automatic email alerts were set up on PubMed until December 2020 and reference lists of key studies and included papers were screened. Two reviewers independently performed the search, study selection, quality appraisal, data extraction, and formal narrative synthesis. In case of disagreement, a third reviewer was involved. Across the 61 included articles, women worked more often part-time and held fewer positions of power in hospitals, on editorial boards, and at the academic level (associate and full professors). Women were less often in relevant positions in scientific articles, had fewer publications, and had a lower H-index. Discrimination and sexual harassment were experienced by up to $40 \%$ and $47 \%$ of female radiologists, respectively. Our study highlights that women in radiology are still underrepresented and play a marginal role in the field, struggling to reach top and leading positions.
\end{abstract}

Keywords: gender inequality; radiology; female empowerment; women

\section{Introduction}

As stated by Paik in the Journal of the American Medical Association [1], "A generation ago a woman's role in medicine was that of a patient". Fortunately, we are witnessing major advancements. Nowadays, the number of women pursuing a medical career is constantly increasing [2] because, in the last decades, strong efforts have been made to enhance gender equality in medicine and, overall, in science. For instance, "to achieve full and equal access to and participation in science for women and girls", the United Nations General Assembly declared 11 February as International Day of Women and Girls in Science [3]. Contemporary feminist movements such as the Women's March as well as foundations such as the Global Fund for Women demonstrate that we are living in a time where women are starting to become empowered $[4,5]$.

Nevertheless, male predominance is still widespread at various levels of medical training [6,7] and women in the academic environment occupying leading positions are underrepresented [6].

Regarding, in particular, women in radiology and related sciences, more than a century has passed since Elizabeth Fleischman opened her own X-ray laboratory in San Francisco in 1896, Florence Ada Stoney became the first female radiologist in the UK in 1898, and Marie Curie was officially acknowledged with the Nobel Prize in Physics in 1903. Regarding this latter achievement, it should not be omitted that the Nobel Prize Committee 
only recognized the equal contribution of Marie Curie because Pierre Curie refused to accept the award unless the crucial role of his wife was acknowledged [8]. More recently, initiatives such as the American Association for Women in Radiology (AAWR), promoting opportunities and networking, represent a crucial support for women in clinical, research, and leadership positions [9]. Nevertheless, numerous challenges still lie ahead and ample opportunities for improvement remain.

In fact, to date, according to the American Medical Association, radiology is still a male-dominated specialty in which men make up $73.2 \%$ of the resident workforce [10]. Several potential reasons for this gender disparity have been suggested, including the fear of radiation exposure, the central role of technology, and the limited interaction with patients [11,12].

Given that healthcare systems closing the gender gap have shown to better perform in terms of organization and clinical outcomes, an increase in the number of women practicing radiology is urgently needed and women and men should also be equally treated and given the same opportunities in this medical field [2,12-15].

Aiming to provide a comprehensive overview of the current role of women in radiological imaging, we performed a systematic review of the literature addressing gender inequality in radiology.

\section{Materials and Methods}

\subsection{Search Strategy}

The following search strategy was used to perform a systematic search of three electronic databases (i.e., PubMed, Scopus, and Web of Science) up to 21 October 2020: ((gender OR women) AND (inequality) AND (radiology)). No restrictions on the time interval or language were applied. Supplementary Text S1 provides a detailed record of the applied search strategy for each electronic database.

Duplicates were automatically removed using Mendeley (Mendeley Software, 20092013 Mendeley Ltd., London, UK). A weekly automatic email alert was set on PubMed to receive notifications of newly published literature (22 October 2020-14 December 2020).

The following inclusion criteria were applied:

- Original articles, case studies, and special reports;

- Articles written in English, German, French, or Italian (languages spoken by the authors);

- Studies reporting quantitative and/or qualitative data on the role of women in radiology;

- Articles covering at least one of the following domains: gender distribution in the

field of radiology, also including radiological societies, academia, residency programs, leadership positions; part-time and full-time employment; income; job satisfaction; perceived discrimination; sexual harassment; academic aspects (authorship, H-index, editorial board membership, grant support); mentorship for residents; private life (relationship, child rearing).

The following exclusion criteria were used:

- Literature reviews of any type, general discussion and opinion papers, comments, editorials, case reports, and book chapters;

- Non-English, Non-German, Non-French, or Non-Italian articles;

- Articles not covering any of the domains mentioned above.

Two reviewers (G.F. and I.M.B.) with 4 years of experience in diagnostic imaging and 7 years of experience in psychology and public health, respectively, independently screened titles and abstracts of the records. Full texts considered as potentially eligible by at least one of the two reviewers were then independently evaluated; in case of dissent about the inclusion of particular full texts, a third reviewer (M.R., with 20 years of experience in psychology and public health) was involved to make the final decision. To identify additional records, the reference lists of key studies and the included papers were screened. 


\subsection{Quality Appraisal}

The methodological quality of the included articles was independently assessed by two reviewers (I.M.B. and R.M.) using the Mixed Methods Appraisal Tool (MMAT) (Version 2018) [16], which allows rating qualitative, quantitative, and mixed methods studies, based on a 5-item criteria list. In case of disagreement, a third reviewer (M.R.) was involved.

\subsection{Data Extraction and Analysis}

Study characteristics such as publication year, journal, country, and study design of each included paper were extracted. For each included paper, we assessed the overall number of female authors/co-authors, also recording if any were in a relevant position (i.e., first, second, last, and/or corresponding author). We recorded publications' impact indexes (i.e., current quartile and impact factor) of the journals where the studies were published.

The main results of the included studies were extracted and summarized in a formal narrative synthesis organized around five main thematic areas:

1. Women in radiology;

2. Work environment;

3. Academic practice;

4. Training and mentorship;

5. Private life.

Descriptive statistics of the collected variables, also grouped according to the homogeneity of data of the selected studies, were performed using SPSS (IBM SPSS Statistics version 26, IBM Armonk, NY, USA).

\section{Results}

Our search provided an overall amount of 2024 records. After screening for titles and abstracts, we assessed 115 full texts for eligibility. Fifty-four articles [17-70] were then excluded because of different reasons such as a mismatch with inclusion criteria and unavailability of the full text (see Figure 1 and Supplementary Table S1). A total number of 61 articles were included [6,7,11,12,71-127].

Fifty-two articles (85.2\%) fulfilled at least four of the quality appraisal criteria [7,11,12, 71,72,75,76,78-82,84,86-89,91-97,99-119,121-127] (see Supplementary Table S2).

\subsection{Characteristics of the Included Studies}

The main characteristics of the primary studies are summarized in Table 1.

All included articles were written in English and published between 1989 and 2020 [6, 7,11,12,71-127] (Figure 2). Most of the studies were conducted in the United States of America (USA) $(n=35)[7,11,73,74,77,79-85,87,88,90-92,94,95,97,100,102,103,105-108,113-$ $116,119,122-124]$ alone or in collaboration with other countries $(n=12)[6,71,75,93,96$, $104,110,111,117,121,127]$. Five articles were published in Canada $[86,98,99,111,126]$ and two in France [76,109]. One article was an international multicenter study [118], and two resulted from a collaboration between Australia and Ireland [89] and Vietnam and Malaysia [12], respectively. One article each was published in Italy [101], Switzerland [78], Saudi Arabia [72], the United Kingdom [120], and South Korea [125].

Most of the articles appeared in Q1 journals (80.3\%), with an impact factor ranging from $0[12,72,98,100,104,118,127]$ to $7.931[80,81,94,97]$. The three most common journals were the American Journal of Roentgenology (i.e., 15 articles) $[71,83,84,86-88,90,95,96,105$, $107,111,114,121,125]$, the Journal of the American College of Radiology (i.e., 12 articles) [7, $73,74,77,79,82,99,102,106,113,115,126]$, and Academic Radiology (i.e., nine articles) [11,91$93,103,108,116,117,119]$.

A woman was the first author in $45(73.8 \%)$ articles $[6,11,73,76,78,80-84,86-90,92-$ $99,102-111,115,116,118-123,125-127]$, the second in 27 (44.3\%) $[6,7,11,72,74,77-82,85,88$, $91,92,97-99,103,113-115,117-119,121,126]$, and the last in 22 (36.1\%) $[77,78,84,85,87,88,90-$ $93,98,99,102,105,106,118-126]$. In five out of the 61 included articles $(8.2 \%)$, there were no women in a relevant position $[12,71,75,100,101]$ (Table 1 ). 
2171 records identified through database searching

을

$\frac{\text { 름 }}{\frac{0}{\overline{1}}}$

엉

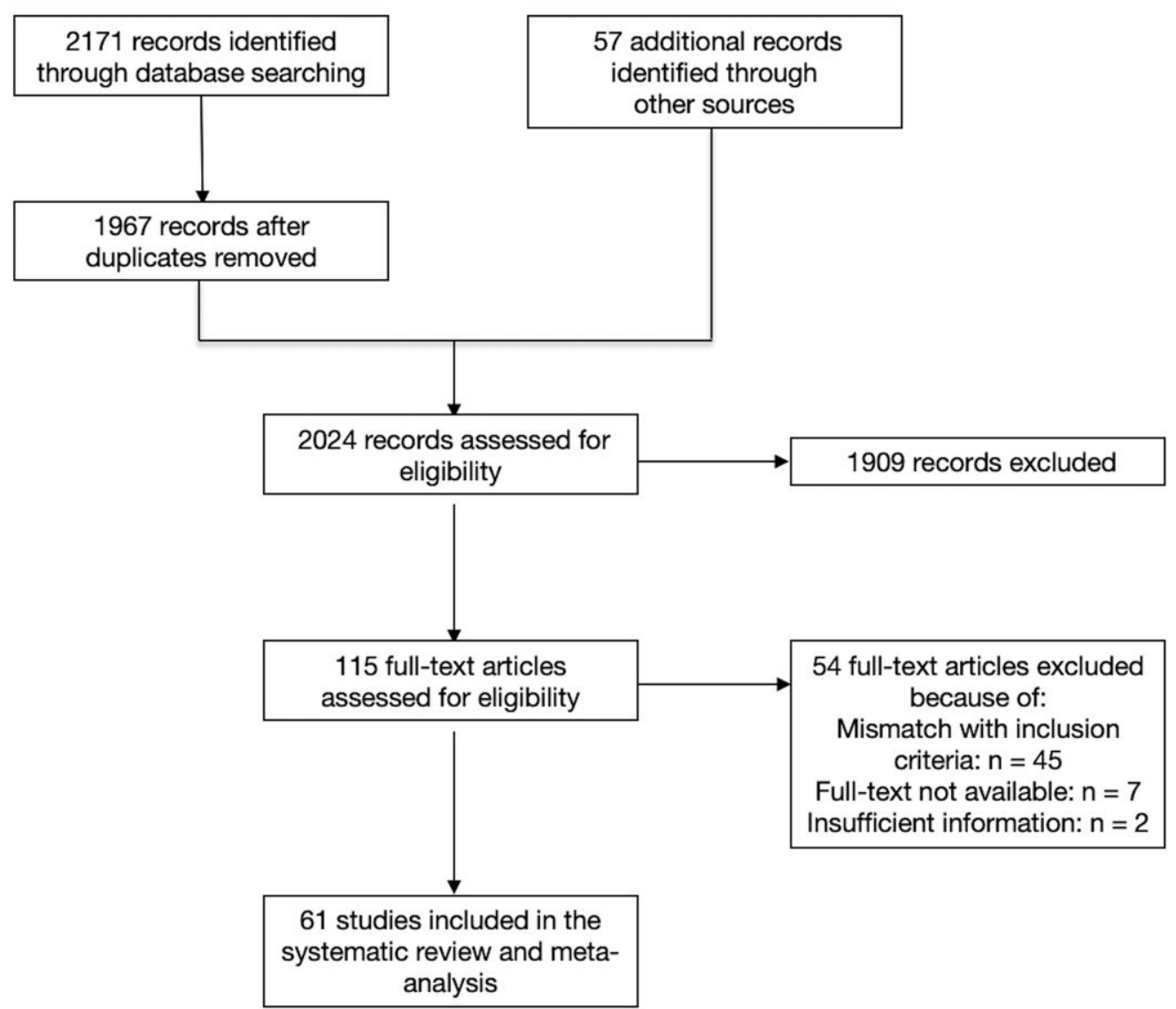

Figure 1. PRISMA flow diagram.

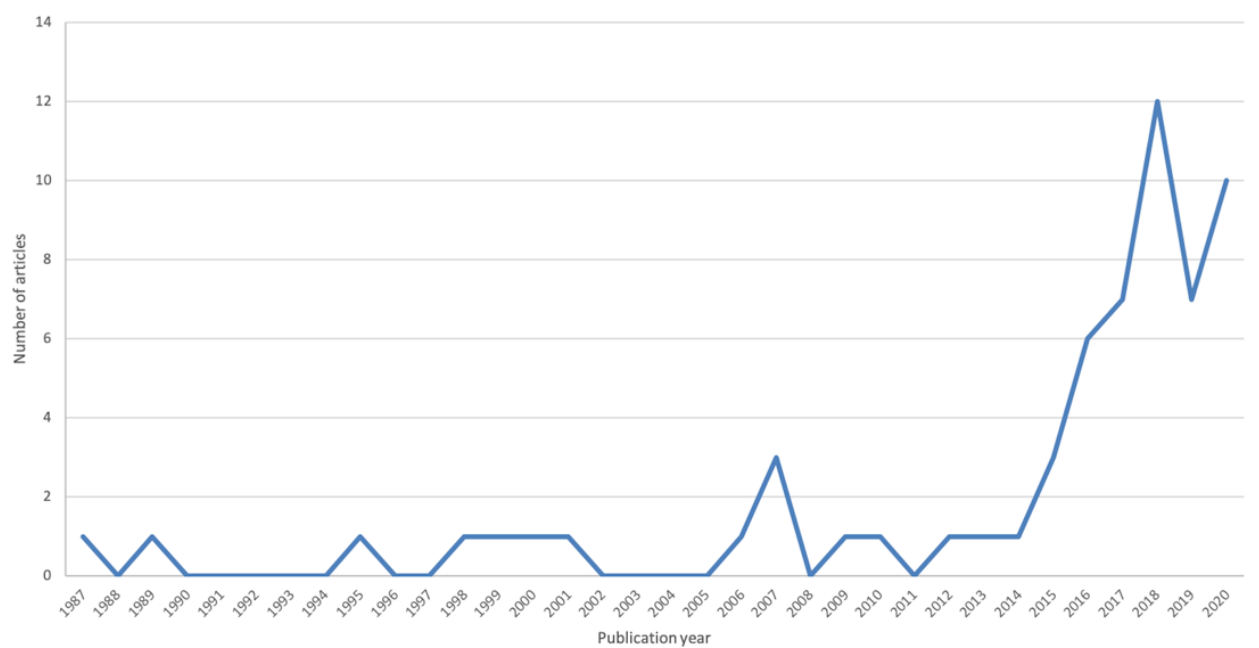

Figure 2. Publishing timeline of the included studies. 
Table 1. Characteristics of the 61 included studies.

\begin{tabular}{|c|c|c|c|c|c|c|}
\hline Authors & Year & Country & Journal & $\begin{array}{l}\text { Quartile } \\
(\mathrm{Q}) *,+\end{array}$ & $\begin{array}{l}\text { Impact } \\
\text { Factor }\end{array}$ & $\begin{array}{l}\text { Relevant Authorship Positions } \\
\text { Occupied by Women }\end{array}$ \\
\hline Abdellatif et al. [71] & 2019 & Canada/USA & American Journal of Roentgenology & Q1 & 3.013 & / \\
\hline Abduljabbar et al. [72] & 2020 & Saudi Arabia & Interactive Journal of Medical Research & / & / & 2nd author \\
\hline Ahmadi et al. [6] & 2018 & Canada/USA & American Journal of Neuroradiology & Q1 & 3.381 & $\begin{array}{l}\text { 1st author } \\
\text { 2nd author }\end{array}$ \\
\hline Arleo et al. [73] & 2016 & USA & Journal of the American College of Radiology & Q1 & 4.268 & 1st author $\ddagger$ \\
\hline Battaglia et al. [75] & 2018 & Canada/USA & Emergency Radiology & Q3 & 1.010 & / \\
\hline Bernard et al. [76] & 2020 & France & European Radiology & Q1 & 4.101 & 1st author \\
\hline Bluth et al. [77] & 2015 & USA & Journal of the American College of Radiology & Q1 & 4.268 & $\begin{array}{l}\text { 2nd author } \\
\text { last author }\end{array}$ \\
\hline Buddeberg-Fischer et al. [78] & 2012 & Switzerland & European Journal of Radiology & Q1 & 2.687 & $\begin{array}{l}\text { 1st author } \\
\text { 2nd author } \\
\text { last author } \ddagger\end{array}$ \\
\hline Campbell et al. [7] & 2018 & USA & Journal of the American College of Radiology & Q1 & 4.268 & 2nd author \\
\hline Cater et al. [11] & 2018 & USA & Academic Radiology & Q1 & 2.488 & $\begin{array}{l}\text { 1st author } \ddagger \\
\text { 2nd author }\end{array}$ \\
\hline Chapman et al. [80] & 2013 & USA & Radiology & Q1 & 7.931 & $\begin{array}{l}\text { 1st author } \\
\text { 2nd author }\end{array}$ \\
\hline Chertoff et al. [81] & 2001 & USA & Radiology & Q1 & 7.931 & $\begin{array}{l}\text { 1st author } \ddagger \\
\text { 2nd author }\end{array}$ \\
\hline Daldrup-Link et al. [82] & 2019 & USA & Journal of the American College of Radiology & Q1 & 4.268 & $\begin{array}{l}\text { 1st author } \ddagger \\
\text { 2nd author }\end{array}$ \\
\hline Deipolyi et al. [83] & 2020 & USA & American Journal of Roentgenology & Q1 & 3.013 & 1st author $\ddagger$ \\
\hline Deitch et al. [84] & 1998 & USA & American Journal of Roentgenology & Q1 & 3.013 & $\begin{array}{l}\text { 1st author } \\
\text { last author }\end{array}$ \\
\hline
\end{tabular}


Table 1. Cont.

\begin{tabular}{|c|c|c|c|c|c|c|}
\hline Authors & Year & Country & Journal & $\begin{array}{l}\text { Quartile } \\
(Q) *,+\end{array}$ & $\begin{array}{l}\text { Impact } \\
\text { Factor }\end{array}$ & $\begin{array}{c}\text { Relevant Authorship Positions } \\
\text { Occupied by Women }\end{array}$ \\
\hline Dial et al. [85] & 1989 & USA & Academic Medicine & Q1 & 5.354 & $\begin{array}{l}\text { 2nd author } \\
\text { last author }\end{array}$ \\
\hline Donovan [86] & 2010 & Canada & American Journal of Roentgenology & Q1 & 3.013 & 1st author $\ddagger$ \\
\hline Duc et al. [12] & 2020 & Vietnam/Malaysia & Acta Informatica Medica & Q3 & / & / \\
\hline Englander et al. [87] & 2018 & USA & American Journal of Roentgenology & Q1 & 3.013 & $\begin{array}{l}\text { 1st author } \ddagger \\
\text { last author }\end{array}$ \\
\hline Fielding et al. [88] & 2007 & USA & American Journal of Roentgenology & Q1 & 3.013 & $\begin{array}{l}\text { 1st author } \\
\text { 2nd author } \\
\text { last author }\end{array}$ \\
\hline Foo et al. [89] & 2020 & Australia/Ireland & Clinical Radiology & Q2 & 2.118 & 1st author $\ddagger$ \\
\hline Frank et al. [90] & 1999 & USA & American Journal of Roentgenology & Q1 & 3.013 & $\begin{array}{l}\text { 1st author } \\
\text { last author }\end{array}$ \\
\hline Grimm et al. [91] & 2017 & USA & Academic Radiology & Q1 & 2.488 & $\begin{array}{l}\text { 2nd author } \\
\text { last author }\end{array}$ \\
\hline Joshi et al. [93] & 2020 & USA/India & Academic Radiology & Q1 & 2.488 & $\begin{array}{l}\text { 1st author } \\
\text { last author } \ddagger\end{array}$ \\
\hline Kapoor et al. [94] & 2017 & USA & Radiology & Q1 & 7.931 & 1st author $\ddagger$ \\
\hline Kapoor et al. [95] & 2017 & USA & American Journal of Roentgenology & Q1 & 3.013 & 1st author $\ddagger$ \\
\hline Khurshid et al. [96] & 2018 & Canada/USA & American Journal of Roentgenology & Q1 & 3.013 & 1st author \\
\hline Lewis et al. [97] & 2007 & USA & Radiology & Q1 & 7.931 & $\begin{array}{l}\text { 1st author } \ddagger \\
\text { 2nd author }\end{array}$ \\
\hline Li et al. [98] & 2020 & Canada & Current Problems in Diagnostic Radiology & Q3 & / & $\begin{array}{l}\text { 1st author } \\
\text { 2nd author } \\
\text { last author }\end{array}$ \\
\hline
\end{tabular}


Table 1. Cont.

\begin{tabular}{|c|c|c|c|c|c|c|}
\hline Authors & Year & Country & Journal & $\begin{array}{l}\text { Quartile } \\
(Q) *,+\end{array}$ & $\begin{array}{l}\text { Impact } \\
\text { Factor }^{+}\end{array}$ & $\begin{array}{c}\text { Relevant Authorship Positions } \\
\text { Occupied by Women }\end{array}$ \\
\hline Liang et al. [99] & 2015 & Canada & Journal of the American College of Radiology & Q1 & 4.268 & $\begin{array}{l}\text { 1st author } \ddagger \\
\text { 2nd author } \\
\text { last author }\end{array}$ \\
\hline Maddu et al. [100] & 2020 & USA & Current Problems in Diagnostic Radiology & Q3 & / & / \\
\hline Magnavita [101] & 2013 & Italy & European Journal of Radiology & Q1 & 2.687 & / \\
\hline McDonald et al. [102] & 2017 & USA & Journal of the American College of Radiology & Q1 & 4.268 & $\begin{array}{l}\text { 1st author } \ddagger \\
\text { last author }\end{array}$ \\
\hline O'Connor et al. [103] & 2018 & USA & Academic Radiology & Q1 & 2.488 & $\begin{array}{l}\text { 1st author } \ddagger \\
\text { 2nd author }\end{array}$ \\
\hline O'Neill et al. [104] & 2019 & Canada/USA & Current Problems in Diagnostic Radiology & Q3 & / & 1st author \\
\hline Owen et al. [105] & 1995 & USA & American Journal of Roentgenology & Q1 & 3.013 & $\begin{array}{l}\text { 1st author } \\
\text { last author }\end{array}$ \\
\hline Piltch-Loeb et al. [106] & 2020 & USA & Journal of the American College of Radiology & Q1 & 4.268 & $\begin{array}{l}\text { 1st author } \\
\text { last author } \ddagger\end{array}$ \\
\hline Piper et al. [108] & 2018 & USA & Academic Radiology & Q1 & 2.488 & 1st author \\
\hline Pyatigorskaya et al. [109] & 2017 & France & Diagnostic and Interventional Imaging & Q2 & 2.527 & 1st author $\ddagger$ \\
\hline Pyatigorskaya et al. [110] & 2017 & USA/France & Diagnostic and Interventional Imaging & Q2 & 2.527 & 1st author $\ddagger$ \\
\hline Qamar et al. [111] & 2018 & Canada/USA & Skeletal Radiology & Q2 & 1.618 & 1st author $\ddagger$ \\
\hline Qamar et al. [112] & 2020 & Canada & American Journal of Roentgenology & Q1 & 3.013 & 1st author \\
\hline Rosenkrantz et al. [113] & 2018 & USA & Journal of the American College of Radiology & Q1 & 4.268 & 2nd author \\
\hline Rosenkrantz et al. [114] & 2019 & USA & American Journal of Roentgenology & Q1 & 3.013 & 2nd author \\
\hline Roubidoux et al. [115] & 2009 & USA & Journal of the American College of Radiology & Q1 & 4.268 & $\begin{array}{l}\text { 1st author } \ddagger \\
\text { 2nd author }\end{array}$ \\
\hline Sadigh et al. [116] & 2019 & USA & Academic Radiology & Q1 & 2.488 & 1st author $\ddagger$ \\
\hline Shah et al. [117] & 2007 & USA/Brazil & Academic Radiology & Q1 & 2.488 & 2nd author \\
\hline
\end{tabular}


Table 1. Cont.

\begin{tabular}{|c|c|c|c|c|c|c|}
\hline Authors & Year & Country & Journal & $\begin{array}{l}\text { Quartile } \\
(Q) *,+\end{array}$ & $\begin{array}{l}\text { Impact } \\
\text { Factor }\end{array}$ & $\begin{array}{c}\text { Relevant Authorship Positions } \\
\text { Occupied by Women }\end{array}$ \\
\hline Vernuccio et al. [118] & 2019 & $\begin{array}{c}\text { Italy/France/UK/Spain/Turkey/ } \\
\text { Mexico/ } \\
\text { Philippines/ } \\
\text { India/Egypt/ } \\
\text { Argentina/ } \\
\text { Mongolia/South Korea/USA }\end{array}$ & Insights into Imaging & Q1 & / & $\begin{array}{l}\text { 1st author } \ddagger \\
\text { 2nd author } \\
\text { last author }\end{array}$ \\
\hline Wah et al. [120] & 2018 & UK & CardioVascular and Interventional Radiology & Q2 & 2.034 & $\begin{array}{l}\text { 1st author } \\
\text { last author }\end{array}$ \\
\hline Wang et al. [121] & 2019 & Canada/USA & American Journal of Roentgenology & Q1 & 3.013 & $\begin{array}{l}\text { 1st author } \ddagger \\
\text { 2nd author }\end{array}$ \\
\hline West et al. [122] & 2016 & USA & Journal of Racial and Ethnic Health Disparities & Q1 & 1.661 & 1st author \\
\hline Xiao et al. [124] & 2018 & USA & Journal of Vascular and Interventional Radiology & Q1 & 3.037 & last author \\
\hline Yun et al. [125] & 2015 & South Korea & American Journal of Roentgenology & Q1 & 3.013 & $\begin{array}{l}\text { 1st author } \ddagger \\
\text { last author }\end{array}$ \\
\hline Zener et al. [126] & 2016 & Canada & Journal of the American College of Radiology & Q1 & 4.268 & $\begin{array}{l}\text { 1st author } \ddagger \\
\text { 2nd author } \\
\text { last author }\end{array}$ \\
\hline Zulfiqar et al. [127] & 2020 & USA/Canada/UK & Current Problems in Diagnostic Radiology & Q3 & / & 1st author \\
\hline
\end{tabular}




\subsection{Women in Radiology}

The average number of women in radiology, including societies' members and subspecialists (e.g., interventional and abdominal radiologists), ranged from $8.2 \%$ to $35.95 \%$ (vs. a range for men from $64.05 \%$ to $90 \%$ ) $[6,11,12,75,77,80,83,85,94,95,98,100,103,105,111-$ $114,116,121,127]$.

In the selected studies, the percentage of part-time employment ranged from $11 \%$ to $50 \%$ for women and from $1 \%$ to $22 \%$ for men $[77,78,81,102,105,119,120]$. Several studies found similar working hours for both genders ( $\sim 50 \mathrm{~h} /$ week) $[81,82,84,105,119]$. Nevertheless, in the survey of Vydareny and colleagues, male associate professors reported working more hours than their female counterparts [119], and Lewis and colleagues, considering all types of practices, showed that men work significantly more hours than women [97].

In terms of income, the survey by Chertoff et al. reported that women earn less than men in both full-time and part-time employment (i.e., USD $229,884 \pm 4470$ vs. USD $269,301 \pm 4310$ and USD 134,161 \pm 5290 vs. USD 160,193 $\pm 19,220$, respectively) [81]. On the contrary, Kapoor et al., screening salary information of state-employed academic radiologists, found similar salaries for both genders (USD 290,660 for men vs. USD 289,797 for women) [95].

Men were overrepresented in leadership positions in most of the studies (percentage range: men $68.09-91.8 \%$ vs. women $8.2-31.9 \%$ ) $[6,11,75,77,100,104,111,112,117,127]$, aside from one on breast imaging which showed a countertendency ( $59.7 \%$ of women vs. $40.3 \%$ of men) [96].

\subsection{Work Environment}

While three studies found similar levels of job satisfaction between men and women $[82,84,97]$, two studies reported significantly higher satisfaction among men $[78,101]$.

Perceived discrimination was assessed in two studies. Namely, Deitch [84] reported that $40 \%$ of women and $1 \%$ of men had experienced discrimination at work. Along the same line, $31 \%$ of female residents and fellows surveyed by Pyatrigorskaya et al. [110] felt discriminated against during application processes for positions or conferences.

Sexual harassment and unwanted sexual attention were addressed in four studies [84, $87,90,110$ ]. Frank et al. [90] reported that $45 \%$ of female radiologists experienced sexual harassment and Pyatigorskaya et al. [110] noted its occurrence for $10 \%$ of French female residents and fellows. Englander and colleagues [87] highlighted that it was more frequent during practice than training ( $47 \%$ vs. $22 \%$ ), while, previously, Deitch et al. [84] showed that unwanted sexual attention was higher during training than practice (39\% vs. $21 \%$ on average).

\subsection{Academic Practice}

Twenty-four studies calculated the distribution of gender in academic rankings [6,12, $75,83,85,94-97,100,102,104,111,112,117,119,121,123,127]$. Due to the heterogeneous ways of computing the gender distribution at each main academic level (i.e., assistant, associate, and full professor), in the following, we separately group the studies which performed within-gender analyses (e.g., numerator: number of women assistant professors; denominator: total amount of women in the sample) from those which assessed the distribution of gender at each academic level (e.g., numerator: number of women assistant professors; denominator: total amount of men and women assistant professors in the sample) (Figure $3 \mathrm{a}, \mathrm{b}$, respectively).

As depicted in Figure 3a, most of the women and men were assistant professors (range 45\% to $95.4 \%$ for the former and $30.7 \%$ to $74 \%$ for the latter) $[75,83,85,94,95,102,119,121,123]$. Moreover, in two studies, it occurred that there were no full professors among all women $[75,85]$.

Figure $3 \mathrm{~b}$ illustrates that a higher percentage of men than women reach associate and full professor positions $[6,12,96,97,100,103,111,112,127]$. It should be noted that among the studies represented in graph $b$, four addressed subspecialties (i.e., one study each for abdominal, breast, musculoskeletal radiology, and neuroradiology) and only the study of 
Khurshid et al. [96], in the field of breast imaging, reported a higher number of female than male associate professors (i.e., $63.5 \%$ vs. $36.5 \%$ ).
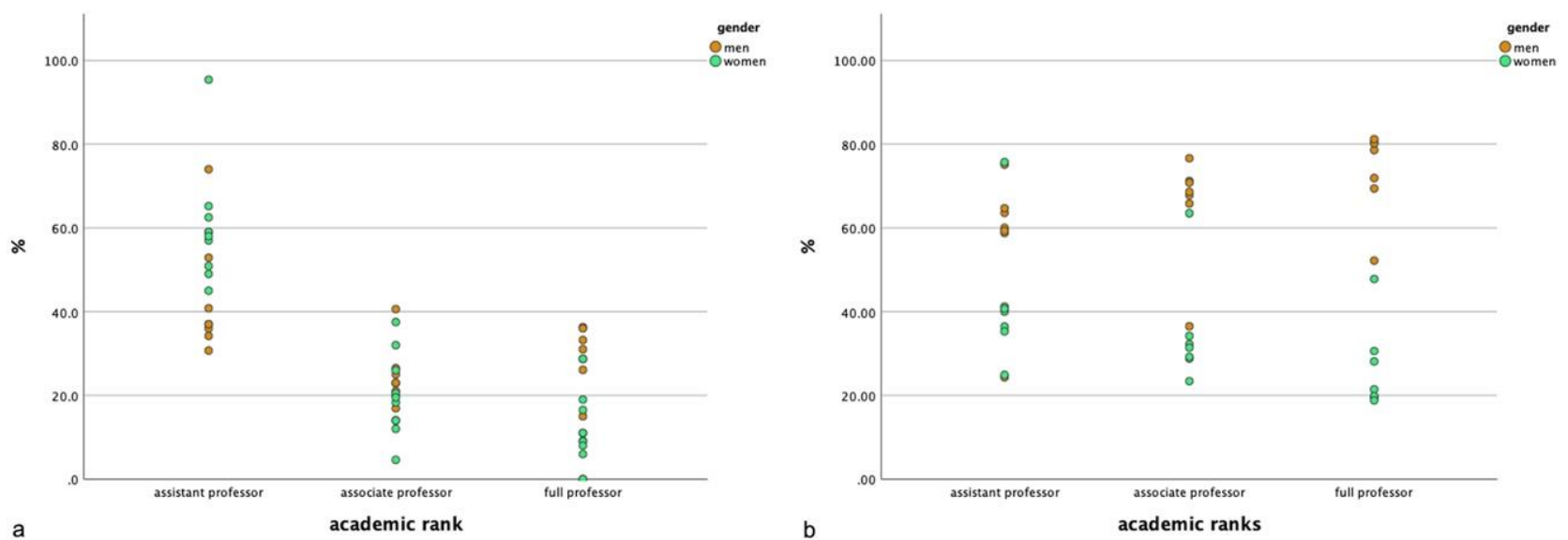

Figure 3. Distribution of academic ranks based on within-gender analyses (a) and analyses at the academic level (b).

Overall, in scientific journals, women were poorly represented as authors (12-28\% of women vs. $72-88 \%$ of men) $[7,99,124]$. Similarly, it emerged that women were less often in a relevant position (first author range: female $17-30 \%$ vs. male $70-84 \%$; last author range: female $9-25 \%$ vs. male $75-91 \%)[76,79,99,103,107,124]$. Nevertheless, two studies observed, along the years, a trend towards an increase in female first, last, and corresponding authorship [109,125].

Two studies reported a higher median number of publications for female assistant and full professors, respectively [111,112], but, on average, women published less than men (range of mean publication number: men $21.99-58.69$ vs. women 14.4-35.59) $[94,95,123,127]$ and had a lower H-index (range of mean H-index: 10-14.65 for men vs. 4.29-11.3 for women) $[75,83,127]$.

Among the editorial board members, women were underrepresented (women: ranging from $13.6 \%$ to $19.3 \%$; men: ranging from $80.87 \%$ to $86.4 \%$ ) [71,93,108]. Moreover, Piper et al. noted that in four radiology journals (i.e., Radiology, American Journal of Radiology, JACR, and Academic Radiology), since each journal's inception, a woman never served as chief editor [108].

More men than women reported grant support $[119,123]$ and received a higher number of grants $[78,83,94,95]$.

\subsection{Training and Mentorship}

Men outnumbered women as applicants, residents, and fellows in radiology (range for men: $71.8-77.2 \%$; range for women: $24-28.1 \%$ ) $[74,79,80,92,122]$. One study reported a greater number of women only in pediatric fellowships [122]. Further, $19 \%$ of women responding to a survey by Englander et al. said that they were discouraged from pursuing a career in radiology.

Mentorship was addressed in several studies $[73,81,86,88,89,91,106,115,126]$. Three articles noted that women with a mentor were underrepresented (range for women: $0-40.3 \%$; range for men: $23.3-64 \%)[72,78,118]$. One study showed that for female medical students, the influence of role models was one of the three most important factors in choosing a career in radiology [73]. Similarly, in a study by Donovan et al., a greater proportion of female than male program directors noted the major role mentorship had played in their own careers (68\% female vs. $35 \%$ male) as well as the importance of female mentors for female radiology residents [86]. 


\subsection{Private Life}

The majority of female radiologists turned out to be married or in a partnership $(67-83.3 \%)[78,87,90]$. The percentage of female radiologists with children ranged from $48 \%$ to $69.8 \%$ [ $[78,87,90]$. In one article, $72.9 \%$ of women considered child rearing as a reason for working part-time in contrast to $5 \%$ of the surveyed men [81]. Child rearing was considered as barrier to career development by female radiologists interviewed by PiltchLoeb and colleagues and by $85.7 \%$ of women and $70.4 \%$ of men assessed by Daldrup-Link et al. $[82,106]$. Similarly, pregnancy-related issues, difficulties in combining work duties with family life, and maternity leave were mentioned by female interventional radiologists as obstacles [120].

\section{Discussion}

The first interesting point emerging from our systematic review is represented by the fact that most of the papers were published in the last five years, suggesting that only recently the radiological community approached this topic. Moreover, the high number of American studies and the paucity of papers from other countries indicate that American radiologists are ahead in openly discussing the matter of gender equality $[7,11,73$, $74,77,79-85,87,88,90-92,94,95,97,100,102,103,105-108,113-116,119,122-124]$. This evidence is also reflected by our finding that most of the articles were published in high-indexed American journals.

Across countries, women in radiology are still underrepresented and hold fewer leadership positions. Breast imaging seems to be an exception with a higher proportion of women not only in the workforce and in executive positions but also as associate professors [96].

Regarding, in particular, academic careers, our results show that women still have lower $\mathrm{H}$-indexes and a lower number of publications and are less frequently in relevant positions in papers. Although this could be seen as a causality dilemma, wondering if women succeed less because they are given less chances or have less chances to succeed because they are not as good as their male counterpart, it can hardly be denied that the difficulties of women to reach top positions are mainly due to unequal opportunities [129], as also recently stated in a Lancet editorial, "the world is still reckoning with pervasive and inexcusable gender inequality underpinned by bias and sexism, and research and health care are not exception" [130].

The "leaky pipeline" is also reflected by the distribution of authorship in our selected studies [131]. Indeed, women were first authors in more than two thirds of the papers but last authors only in around one third. This indicates that even if it comes to the matter of gender inequality, in most of the cases, men are still leading research projects. While this finding may also imply that male radiologists are genuinely interested in the topic of gender differences, it primarily suggests that more men than women hold senior positions in academic radiology, that is, positions which give them the opportunity to supervise those projects.

Similarly, our study showed that the number of women assistant professors is higher than that of men but that an opposite trend for associate and full professorship exists. One might argue that the disparities observed at the more senior level will become less prevalent with time, as the natural progression from assistant professors to professors occurs. However, our finding is based not only on recent studies but also on older articles published in 1987 [123], 1989 [85], and 2000 [119], thus suggesting that in the last two decades, such progression did not naturally occur. Considering, however, that there has been a growing awareness of the issue of gender inequality in radiology and that the percentage of female authorship has been steadily increasing in recent years $[99,107,109]$, we expect these disparities to diminish in the future.

Challenges that women have to face in their practice are not only associated with their career but also with the work environment. For instance, they are still affected by rigid gender roles, as indicated by the finding that larger shares of women work 
part-time and struggle in aligning work and family, considering child rearing as an obstacle $[81,82,106,120]$. Moreover, women feel discriminated against and many are still victims of sexual harassment throughout their career $[84,87,90]$. In creating paths of change, tailored programs promoting respect in the workplace should be implemented internationally $[132,133]$. Further, to foster inclusive workplaces, family-supportive policies, flexible work opportunities, and programs ensuring a fair distribution of promotions should be encouraged [66]. Despite some controversial results in the assessed literature regarding the gender pay gap [81,95], salary equity should be always guaranteed [66].

Last, medical schools and residency programs certainly play a crucial role in closing the gender gap. Since several studies addressed the importance of mentoring in choosing a career in radiology and one even highlighted the significant impact of role models on women, we call for mentoring programs such as the one at the Massachusetts General Hospital [134] and the Women in Radiology Group at Indiana University [135].

A number of weaknesses have to be considered.

First, intrinsic limitations associated with systematic reviews such as the potential impact of studies not detected by the search process, also because of the relatively short search strategy, must be taken into account. To compensate for this shortcoming, we additionally screened the reference lists of the included studies and key papers.

Moreover, the primary studies differed in the data analysis and description (e.g., median and mean values for the number of women in leadership positions in the academic field) of some variables, hampering their synthesis.

Although we did not perform any in-depth evaluation of different subspecialties due to the small number of articles focused on each subspecialty, we synthesized the main findings. For instance, as mentioned above, breast imaging showed a higher female representation, while, on the contrary, in interventional, abdominal, and musculoskeletal radiology, a male predominance was reported.

\section{Conclusions}

In conclusion, our systematic review highlights that women in radiology are still underrepresented and play a marginal role, struggling to reach top and leading positions. Thus, continued efforts are still needed to see the vision of Sandra Day O'Connor, the first female justice of the Supreme Court of the United States, who realized: "As women achieve power, the barriers will fall. As society sees what women can do, as women see what women can do, there will be more women out there doing things, and we'll all be better off for it" [136].

Supplementary Materials: The following are available online at https:/ /www.mdpi.com/1660-460 1/18/4/1542/s1, Supplementary Text S1: Search strategy and retrieved records from each electronic databases; Supplementary Table S1: List of excluded studies; Supplementary Table S2: Quality appraisal of included studies.

Author Contributions: Conceptualization, G.F., I.M.B., and C.G.; data curation, I.M.B.; formal analysis, G.F. and I.M.B.; methodology, G.F., I.M.B., M.R., and R.M.; supervision, C.G.; visualization, G.F.; writing—original draft, G.F. and I.M.B.; writing—review and editing, I.M.B., M.R., R.M., and C.G. All authors have read and agreed to the published version of the manuscript.

Funding: This research received no external funding.

Institutional Review Board Statement: Not applicable.

Informed Consent Statement: Not applicable.

Data Availability Statement: The data presented in this study are available on request from the corresponding author.

Conflicts of Interest: The authors declare no conflict of interest. 


\section{References}

1. Paik, J.E. The Feminization of Medicine. JAMA 2000, 283, 666. [CrossRef]

2. Bailey, E.L. Life and Times. Women in medicine: Increasing in number but not regard. Br. J. Gen. Pract. 2020, 70, 296. [CrossRef]

3. United Nations. International Day of Women and Girls in Science 11 February. Available online: https://www.un.org/en/ observances / women-and-girls-in-science-day (accessed on 13 December 2020).

4. Women's March. Available online: https:/ / womensmarch.com (accessed on 13 December 2020).

5. Global Fund for Women. Available online: https://www.globalfundforwomen.org (accessed on 13 December 2020).

6. Ahmadi, M.; Khurshid, K.; Sanelli, P.C.; Jalal, S.; Chahal, T.; Norbash, A.; Nicolaou, S.; Castillo, M.; Khosa, F. Influences for Gender Disparity in Academic Neuroradiology. Am. J. Neuroradiol. 2018, 39, 18-23. [CrossRef] [PubMed]

7. Campbell, J.C.; Yoon, S.C.; Grimm, L.J. Authorship and Impact of Gender-Specific Research in Major Radiology Journals. J. Am. Coll. Radiol. 2018, 16, 240-243. [CrossRef] [PubMed]

8. DeBenedectis, C.M. Celebrating the achievements of women in radiology. Clin. Imaging 2020, 59, 1-2. [CrossRef] [PubMed]

9. American Association for Women in Radiology. Available online: https://www.aawr.org/Home (accessed on 13 December 2020).

10. American Medical Association. Specialty Profiles. Available online: https://www.ama-assn.org/residents-students/specialtyprofiles/these-medical-specialties-have-biggest-gender-imbalances (accessed on 13 December 2020).

11. Cater, S.; Yoon, S.C.; Lowell, D.A.; Campbell, J.C.; Sulioti, G.; Qin, R.; Jiang, B.; Grimm, L.J. Bridging the Gap: Identifying Global Trends in Gender Disparity among the Radiology Physician Workforce. Acad. Radiol. 2018, 25, 1052-1061. [CrossRef]

12. Duc, N.M.; Huy, H.Q.; Keserci, B.; Thong, P.M. Gender Disparity in Vietnamese Radiological Societies: A Preliminary Observational Study. Acta Inform. Med. 2020, 28, 71-74. [CrossRef]

13. Woetzel, J.; Madgavkar, A.; Ellingrud, K.; Labaye, E.; Devillard, S.; Kutcher, E.; Manyika, J.; Dobbs, R.; Krishnan, M. The Power of Parity: How Advancing Women's Equality Can Add \$12 Trillion to Global Growth. Available online: https: / www.mckinsey.com/ featured-insights / employment-and-growth/how-advancing-womens-equality-can-add-12-trillion-to-global-growth (accessed on 14 January 2021).

14. Tsugawa, Y.; Jena, A.B.; Figueroa, J.F.; Orav, E.J.; Blumenthal, D.M.; Jha, A.K. Comparison of hospital mortality and readmission rates for medicare patients treated by male vs female physicians. JAMA Intern. Med. 2017, 177, 206-213. [CrossRef]

15. Wallis, C.J.; Ravi, B.; Coburn, N.; Nam, R.K.; Detsky, A.S.; Satkunasivam, R. Comparison of postoperative outcomes among patients treated by male and female surgeons: A population based matched cohort study. BMJ 2017, 359, 4366. [CrossRef]

16. Mixed Method Appraisal Tool. Available online: http://mixedmethodsappraisaltoolpublic.pbworks.com/w/file/fetch/127916 259/MMAT_2018_criteria-manual_2018-08-01_ENG.pdf (accessed on 13 December 2020).

17. Abdellatif, W.; Ding, J.; Jalal, S.; Chopra, S.; Butler, J.; Ali, I.T.; Shah, S.; Khosa, F. Leadership Gender Disparity Within ResearchIntensive Medical Schools: A Transcontinental Thematic Analysis. J. Contin. Educ. Health Prof. 2019, 39, 243-250. [CrossRef] [PubMed]

18. Aldrich, M.C.; Cust, A.E.; Raynes-Greenow, C. International Network for Epidemiology in Policy. Gender equity in epidemiology: A policy brief. Ann. Epidemiol. 2019, 35, 1-3. [CrossRef]

19. Anim-Sampong, S.; Arthur, L.; Nkansah, J.A.; Botwe, B.O. Women in Radiography Practice in Ghana: Motivating and Demotivating Factors. Radiol. Technol. 2018, 89, 337-343. [PubMed]

20. Arleo, E.K.; Parikh, J.R.; Wolfman, D.; Gridley, D.; Bender, C.; Bluth, E. Utilization of the Family and Medical Leave Act in Radiology Practices According to the 2016 ACR Commission on Human Resources Workforce Survey. J. Am. Coll. Radiol. 2016, 13, 1440-1446. [CrossRef]

21. Baerlocher, M.O.; Walker, M. Does gender impact upon application rejection rate among Canadian radiology residency applicants? Can. Assoc. Radiol. J. 2005, 56, 232-237.

22. Beeler, W.H.; Griffith, K.A.; Jones, R.D.; Chapman, C.H.; Holliday, E.B.; Lalani, N.; Wilson, E.; Bonner, J.A.; Formenti, S.C.; Hahn, S.M.; et al. Gender, Professional Experiences, and Personal Characteristics of Academic Radiation Oncology Chairs: Data to Inform the Pipeline for the 21st Century. Int. J. Radiat. Oncol. Biol. Phys. 2019, 104, 979-986. [CrossRef]

23. Belinsky, S.B.; Blagg, J.D. Analyzing the glass ceiling effect among radiologic technologists. Radiol. Technol. 2011, 82, 300-310.

24. Bendels, M.; Müller, R.; Brueggmann, D.; Groneberg, D.A. Gender disparities in high-quality research revealed by Nature Index journals. PLoS ONE 2018, 13, e0189136. [CrossRef]

25. Bluth, E.I.; Cox, J.; Bansal, S.; Green, D. The 2015 ACR Commission on Human Resources Workforce Survey. J. Am. Coll. Radiol. 2015, 12, 1137-1141. [CrossRef]

26. Boechat, M.I. Women in pediatric radiology. Pediatr. Radiol. 2010, 40, 484-487. [CrossRef]

27. Bouchardy, J.; Testuz, A.; Blanche, C. Gender aspects in cardiac imaging. Cardiovasc. Med. 2019, 22, 02069. [CrossRef]

28. Boulis, A. The Evolution of Gender and Motherhood in Contemporary Medicine. Ann. Am. Acad. Pol. Soc. Sci. 2004, 596, 259-261. [CrossRef]

29. Branstetter, B.; Faix, L.E.; Humphrey, A.L.; Schumann, J.B. Preclinical medical student training in radiology: The effect of early exposure. AJR Am. J. Roentgenol. 2007, 188, 9-14. [CrossRef]

30. Bundy, B.D.; Bellemann, N.; Weber, M.A. Vereinbarkeit von Familie und ärztlichem Beruf [Compatibility of family and medical profession]. Radiologe 2011, 51, 801-803. [CrossRef]

31. Campbell, J.C.; Yoon, S.C.; Grimm, L.J. Collaboration Metrics Among Female and Male Researchers: A 5-Year Review of Publications in Major Radiology Journals. Acad. Radiol. 2018, 25, 951-954. [CrossRef] 
32. Chan, H.F.; Torgler, B. Gender differences in performance of top cited scientists by field and country. Scientometrics 2020, 125, 2421-2447. [CrossRef]

33. Choi, M.; Fuller, C.D.; Thomas, C.R. Estimation of citation-based scholarly activity among radiation oncology faculty at domestic residency-training institutions: 1996-2007. Int. J. Radiat. Oncol. Biol. Phys. 2009, 74, 172-178. [CrossRef] [PubMed]

34. Estrada-Ramírez, K.P.; Miranda-Lora, A.L.; Sandoval-Quiroa, R.C.; Ávila-Montiel, D.; Mier-Prado, M.J.; Garduño-Espinosa, J. Gender gap in the authorship of published articles in the Boletín Médico del Hospital Infantil de México. Bol. Med. Hosp. Infant. Mex. 2018, 75, 216-223. [CrossRef]

35. Ekpo, E.U.; Snaith, B.; Harris, M.A.; McEntee, M.F. Doctoral profile of the medical radiation sciences: A baseline for Australia and New Zealand. J. Med. Radiat. Sci. 2017, 64, 195-202. [CrossRef]

36. Frandsen, T.F.; Jacobsen, R.H.; Ousager, J. Gender gaps in scientific performance: A longitudinal matching study of health sciences researchers. Scientometrics 2020, 124, 1511-1527. [CrossRef]

37. Giner-Soriano, M.; López-Pereiro, O.; Zabaleta-Del-Olmo, E.; Pons-Vigués, M.; Morros, R.; Gómez-Lumbreras, A. Análisis bibliométrico de la autoría femenina en artículos originales en la revista ATENCIÓN PRIMARIA [Bibliometric analysis of female authorship in original articles in the journal ATENCIÓN PRIMARIA]. Aten. Primaria 2019, 53, 12-18. [CrossRef]

38. Grimm, L.J.; Ngo, J.; Pisano, E.D.; Yoon, S. Men (and Women) in Academic Radiology: How Can We Reduce the Gender Discrepancy? AJR Am. J. Roentgenol. 2016, 206, 678-680. [CrossRef]

39. Grimm, L.J.; Redmond, R.A.; Campbell, J.C.; Rosette, A.S. Gender and Racial Bias in Radiology Residency Letters of Recommendation. J. Am. Coll. Radiol. 2020, 17, 64-71. [CrossRef] [PubMed]

40. Grissom, N.M.; Reyes, T.M. Let's call the whole thing off: Evaluating gender and sex differences in executive function. Neuropsychopharmacology 2019, 44, 86-96. [CrossRef]

41. Guss, Z.D.; Chen, Q.; Hu, C.; Guss, L.G.; DeWeese, T.L.; Terezakis, S.A. Differences in Physician Compensation Between Men and Women at United States Public Academic Radiation Oncology Departments. Int. J. Radiat. Oncol. Biol. Phys. 2019, 103, 314-319. [CrossRef]

42. Hamberg, K. Gender bias in medicine. Women's Health 2008, 4, 237-243. [CrossRef] [PubMed]

43. Hamid, S.; Inam, S.H.A.; Jamil, H.; Zeb, R. Speciality preference with respect to gender among medical students of Pakistan. J. Pak. Med. Assoc. 2019, 69, 1190-1193.

44. Hamidizadeh, R.; Jalal, S.; Pindiprolu, B.; Tiwana, M.H.; Macura, K.J.; Qamar, S.R.; Nicolaou, S.; Khosa, F. Influences for Gender Disparity in the Radiology Societies in North America. AJR Am. J. Roentgenol. 2018, 211, 831-838. [CrossRef] [PubMed]

45. Harrington, S.G.; Harvey, H.B. Quality Improvement and Reimbursements: An Opportunity to Address Health Disparities in Radiology. J. Am. Coll. Radiol. 2019, 16, 635-637. [CrossRef]

46. Heiligers, P.J.; de Jong, J.D.; Groenewegen, P.P.; Hingstman, L.; Völker, B.; Spreeuwenberg, P. Is networking different with doctors working part-time? Differences in social networks of part-time and full-time doctors. BMC Health Serv. Res. 2008, 8, 204. [CrossRef]

47. Hinze, S.W. Inside Medical Marriages: The Effect of Gender on Income. Work Occup. 2000, 27, 464-499. [CrossRef]

48. Holliday, E.B.; Jagsi, R.; Wilson, L.D.; Choi, M.; Thomas, C.R.; Fuller, C.D. Gender differences in publication productivity, academic position, career duration, and funding among US academic radiation oncology faculty. Acad. Med. 2014, 89, 767-773. [CrossRef]

49. Auf, A.I.; Awadalla, H.; Ahmed, M.E.; Ahmed, M.H. Comparing the participation of men and women in academic medicine in medical colleges in Sudan: A cross-sectional survey. J. Educ. Health Promot. 2019, 8, 31.

50. Jalilianhasanpour, R.; Chen, H.; Caffo, B.; Johnson, P.; Beheshtian, E.; Yousem, D.M. Are Women Disadvantaged in Academic Radiology? Acad. Radiol. 2020, 27, 1760-1766. [CrossRef] [PubMed]

51. Jutras, M.; Malekafzali, L.; Jung, S.; Das, P.; Qamar, S.R.; Khosa, F. National Institutes of Health: Gender Differences in Radiology Funding. Acad. Radiol. 2020. [CrossRef]

52. Kalaitzi, S.; Czabanowska, K.; Fowler-Davis, S.; Brand, H. Women leadership barriers in healthcare, academia and business. Equal. Divers. Incl. 2017, 36, 457-474. [CrossRef]

53. Madsen, L.B.; Kalantarova, S.; Jindal, R.; Akerman, M.; Fefferman, N.R.; Hoffmann, J.C. National survey to assess gender, racial, and ethnic differences among radiology residency applicants regarding factors impacting program selection. Acad. Radiol. 2020. [CrossRef]

54. Martin, C.A.; Woodring, J.H. Attitudes toward women in radiology. J. Am. Med. Women's Assoc. 1972, 41, 50-53.

55. McClelland, S.; Holland, K.J. You, Me, or Her: Leaders' Perceptions of Responsibility for Increasing Gender Diversity in STEM Departments. Psychol. Women Q. 2014, 39, 210-225. [CrossRef]

56. Moghimi, S.; Khurshid, K.; Jalal, S.; Qamar, S.R.; Nicolaou, S.; Fatima, K.; Khosa, F. Gender Differences in Leadership Positions Among Academic Nuclear Medicine Specialists in Canada and the United States. AJR Am. J. Roentgenol. 2019, 212, 146-150. [CrossRef]

57. Morris, E.; Kubik-Huch, R.A.; Abdel-Wahab, M.; Balogun, E.; Beardmore, C.; Beets-Tan, R.; Boyd-Thorpe, A.; Derchi, L.; Fuchsjäger, M.; Husband, J.; et al. Women in focus: Advice from the front lines on how to enable well-being and build resilience. Insights Imaging 2020, 11, 55. [CrossRef] [PubMed]

58. Obodovskiy, I. Radiation: Fundamentals, Applications, Risks, and Safety; Elsevier: Amsterdam, The Netherlands, 2019. 
59. Osborn, V.W.; Doke, K.; Griffith, K.A.; Jones, R.; Lee, A.; Maquilan, G.; Masters, A.H.; Albert, A.A.; Dover, L.L.; Puckett, L.L.; et al. A Survey Study of Female Radiation Oncology Residents' Experiences to Inform Change. Int. J. Radiat. Oncol. Biol. Phys. 2019, 104, 999-1008. [CrossRef] [PubMed]

60. Perez, Y.V.; Kesselman, A.; Abbey-Mensah, G.; Walsh, J. A Glance at Gender-Specific Preferences Influencing Interventional Radiology Selection. J. Vasc. Interv. Radiol. 2016, 27, 142-143. [CrossRef]

61. Pfleiderer, B.; Bortul, M.; Palmisano, S.; Rodde, S.; Hasebrook, J. Improving female physician's careers in academic medicine: Chances and challenges. Best Pract. Res. Clin. Anaesthesiol. 2018, 32, 15-23. [CrossRef] [PubMed]

62. Rodrigues, J.J. Advancing Medical Practice through Technology: Applications for Healthcare Delivery, Management, and Quality; IGI Global: Hershey, PA, USA, 2013.

63. Rosen, M.P.; Davis, R.B.; Lesky, L.G. Utilization of outpatient diagnostic imaging. Does the physician's gender play a role? J. Gen. Intern. Med. 1997, 12, 407-411. [CrossRef]

64. Safdar, B.; Greenberg, M.R. Applying the gender lens to emergency care: From bench to bedside. Acad. Emerg. Med. 2014, 21, 1325-1328. [CrossRef]

65. Sepulveda, K.A.; Paladin, A.M.; Rawson, J.V. Gender Diversity in Academic Radiology Departments: Barriers and Best Practices to Optimizing Inclusion and Developing Women Leaders. Acad. Radiol. 2018, 25, 556-560. [CrossRef]

66. Spalluto, L.B.; Arleo, E.K.; Lewis, M.C.; Oates, M.E.; Macura, K.J. Addressing Needs of Women Radiologists: Opportunities for Practice Leaders to Facilitate Change. Radiographics 2018, 38, 1626-1637. [CrossRef]

67. Strax, R. Diversity Committee: A Means to Local Gender Equity. J. Am. Coll. Radiol. 2019, 16, 407. [CrossRef]

68. Vosper, M.R.; Price, R.C.; Ashmore, L.A. Careers and destinations of radiography students from the University of Hertfordshire. Radiography 2005, 11, 79-88. [CrossRef]

69. Webb, E.M.; Bucknor, M.D.; Naeger, D.M. Diversity and Inclusion: Now Radiology Must Walk the Walk. J. Am. Coll. Radiol. 2018, 15, 687-688. [CrossRef]

70. Weigel, K.S.; Kubik-Huch, R.A.; Gebhard, C. Women in radiology: Why is the pipeline still leaking and how can we plug it? Acta Radiol. 2020, 61, 743-748. [CrossRef]

71. Abdellatif, W.; Shao, M.; Jalal, S.; Ding, J.; Vijayasarathi, A.; Sanelli, P.C.; Castillo, M.; Norbash, A.; O’Neill, S.B.; Nicolaou, S.; et al Novel Geographic Thematic Study of the Largest Radiology Societies Globally: How Is Gender Structure Biased Within Editorial Boards? AJR Am. J. Roentgenol. 2019, 213, 1-6. [CrossRef]

72. Abduljabbar, A.H.; Alnajjar, S.F.; Alshamrani, H.; Bashamakh, L.F.; Alshehri, H.Z.; Alqulayti, W.M.; Wazzan, M.A. The Influence of Gender on the Choice of Radiology as a Specialty Among Medical Students in Saudi Arabia: Cross-Sectional Study. Interact. J. Med. Res. 2020, 9, 2. [CrossRef]

73. Arleo, E.K.; Bluth, E.; Francavilla, M.; Straus, C.M.; Reddy, S.; Recht, M. Surveying Fourth-Year Medical Students Regarding the Choice of Diagnostic Radiology as a Specialty. J. Am. Coll. Radiol. 2016, 13, 188-195. [CrossRef]

74. Baker, S.; Barry, M.; Chaudhry, H.; Hubbi, B. Women as radiologists: Are there barriers to entry and advancement? J. Am. Coll. Radiol. 2006, 3, 131-134. [CrossRef] [PubMed]

75. Battaglia, F.; Shah, S.; Jalal, S.; Khurshid, K.; Verma, N.; Nicolaou, S.; Reddy, S.; John, S.; Khosa, F. Gender disparity in academic emergency radiology. Emerg. Radiol. 2018, 26, 21-28. [CrossRef] [PubMed]

76. Bernard, C.; Pommier, R.; Vilgrain, V.; Ronot, M. Gender gap in articles published in European Radiology and CardioVascular and Interventional Radiology: Evolution between 2002 and 2016. Eur. Radiol. 2020, 30, 1011-1019. [CrossRef] [PubMed]

77. Bluth, E.I.; Bansal, S.; Macura, K.J.; Fielding, J.; Truong, H. Gender and the radiology workforce: Results of the 2014 ACR workforce survey. J. Am. Coll. Radiol. 2015, 12, 155-157. [CrossRef]

78. Buddeberg-Fischer, B.; Hoffmann, A.; Christen, S.; Weishaupt, D.; Kubik-Huch, R.A. Specialising in radiology in Switzerland: Still attractive for medical school graduates? Eur. J. Radiol. 2012, 81, 1644-1651. [CrossRef] [PubMed]

79. Campbell, J.C.; Yoon, S.C.; Cater, S.W.; Grimm, L.J. Factors Influencing the Gender Breakdown of Academic Radiology Residency Programs. J. Am. Coll. Radiol. 2017, 14, 958-962. [CrossRef] [PubMed]

80. Chapman, C.H.; Hwang, W.T.; Both, S.; Thomas, J.C.R.; Deville, C. Current status of diversity by race, Hispanic ethnicity, and sex in diagnostic radiology. Radiology 2014, 270, 232-240. [CrossRef]

81. Chertoff, J.D.; Bird, C.E.; Amick, B.C. Career paths in diagnostic radiology: Scope and effect of part-time work. Radiology 2001, 221, 485-494. [CrossRef]

82. Daldrup-Link, H.; Villavasso, K.; Zhao, Q.; Lu, Y.; Ranieri, A.; Simard, C.; Gambhir, S.S. How to Prevent a Leaky Pipeline in Academic Radiology: Insights from a Faculty Survey. J. Am. Coll. Radiol. 2019, 16, 1220-1224. [CrossRef]

83. Deipolyi, A.R.; Becker, A.S.; Covey, A.M.; Chimonas, S.C.; Rosenkrantz, A.B.; Forman, H.P.; Copen, W.A. Gender Disparity in Industry Relationships With Academic Interventional Radiology Physicians. AJR Am. J. Roentgenol. 2020, 215, 494-501. [CrossRef]

84. Deitch, C.H.; Sunshine, J.H.; Chan, W.C.; Shaffer, K.A. Women in the radiology profession: Data from a 1995 national survey. AJR Am. J. Roentgenol. 1998, 170, 263-270. [CrossRef] [PubMed]

85. Dial, T.H.; Bickel, J.; Lewicki, A.M. Sex differences in rank attainment among radiology and internal medicine faculty. Acad. Med. 1989, 64, 198-202. [CrossRef] [PubMed]

86. Donovan, A. Views of radiology program directors on the role of mentorship in the training of radiology residents. AJR Am. J. Roentgenol. 2010, 194, 704-708. [CrossRef] [PubMed] 
87. Englander, M.J.; O'Horo, S.K. JOURNAL CLUB: Women in Interventional Radiology: How Are We Doing? AJR Am. J. Roentgenol. 2018, 211, 724-729. [CrossRef]

88. Fielding, J.R.; Major, N.M.; Mullan, B.F.; Neutze, J.A.; Shaffer, K.; Wilcox, C.B.; Paynter, L.; Pisano, E.D. Choosing a specialty in medicine: Female medical students and radiology. AJR Am. J. Roentgenol. 2007, 188, 897-900. [CrossRef]

89. Foo, M.; Maingard, J.; Wang, M.; Kok, H.K.; Chandra, R.V.; Jhamb, A.; Chong, W.; Lee, M.J.; Brooks, M.; Asadi, H. Women in interventional radiology: Insights into Australia's gender gap. Clin. Radiol. 2020, 75, 560.e1-560.e7. [CrossRef]

90. Frank, E.; Vydareny, K. Characteristics of women radiologists in the United States. AJR Am. J. Roentgenol. 1999, 173, 531-536. [CrossRef] [PubMed]

91. Grimm, L.J.; Lowell, D.A.; Cater, S.W.; Yoon, S.C. Differential Motivations for Pursuing Diagnostic Radiology by Gender: Implications for Residency Recruitment. Acad. Radiol. 2017, 24, 1312-1317. [CrossRef] [PubMed]

92. Hewett, L.; Lewis, M.; Collins, H.; Gordon, L. Gender Bias in Diagnostic Radiology Resident Selection, Does it Exist? Acad. Radiol. 2016, 23, 101-107. [CrossRef]

93. Joshi, A.; Kong, W.; Yu, S.; Balasubramanian, S.; Jankharia, B.; Agarwal, P.P. Female Representation on Radiology Journal Editorial Boards Around the World: Geographical Differences and Temporal Trends. Acad. Radiol. 2020. [CrossRef]

94. Kapoor, N.; Blumenthal, D.M.; Smith, S.E.; Ip, I.K.; Khorasani, R. Gender Differences in Academic Rank of Radiologists in US Medical Schools. Radiology 2016, 283, 140-147. [CrossRef]

95. Kapoor, N.; Blumenthal, D.M.; Smith, S.E.; Ip, I.K.; Khorasani, R. Sex Differences in Radiologist Salary in US Public Medical Schools. AJR Am. J. Roentgenol. 2017, 209, 953-958. [CrossRef]

96. Khurshid, K.; Shah, S.; Ahmadi, M.; Jalal, S.; Carlos, R.; Nicolaou, S.; Khosa, F. Gender Differences in the Publication Rate Among Breast Imaging Radiologists in the United States and Canada. AJR Am. J. Roentgenol. 2018, 210, 2-7. [CrossRef]

97. Lewis, R.S.; Bhargavan, M.; Sunshine, J.H. Women Radiologists in the United States: Results from the American College of Radiology's 2003 Survey. Radiology 2007, 242, 802-810. [CrossRef] [PubMed]

98. Li, O.; Ross, M.; Wiseman, D. Women in Interventional Radiology: Exploring the Gender Disparity in Canada. Curr. Probl. Diagn. Radiol. 2020, 50, 115-118. [CrossRef]

99. Liang, T.; Zhang, C.; Khara, R.M.; Harris, A.C. Assessing the Gap in Female Authorship in Radiology: Trends Over the Past Two Decades. J. Am. Coll. Radiol. 2015, 12, 735-741. [CrossRef] [PubMed]

100. Maddu, K.; Amin, P.; Jalal, S.; Mauricio, C.; Norbash, A.; Ho, M.L.; Sanelli, P.C.; Ali, I.T.; Shah, S.; Abujudeh, H.; et al. Gender Disparity in Radiology Society Committees and Leadership in North America and Comparison with Other Continents. Curr. Probl. Diagn. Radiol. 2020. [CrossRef]

101. Magnavita, N. Is there a gender gap in Italian radiology? A cross-sectional study. Eur. J. Radiol. 2013, 82, 502-507. [CrossRef] [PubMed]

102. McDonald, J.S.; McDonald, R.J.; Davenport, M.S.; Jaffe, T.A.; Cook, T.S.; Kallmes, D.F.; Kotsenas, A.L. Gender and Radiology Publication Productivity: An Examination of Academic Faculty from Four Health Systems in the United States. J. Am. Coll. Radiol. 2017, 14, 1100-1108. [CrossRef] [PubMed]

103. O'Connor, E.E.; Chen, P.; Weston, B.; Anderson, R.; Zeffiro, T.; Ahmed, A.; Zeffiro, T.A. Gender Trends in Academic Radiology Publication in the United States Revisited. Acad. Radiol. 2018, 25, 1062-1069. [CrossRef]

104. O’Neill, S.B.; Maddu, K.; Jalal, S.; Yeo, S.; Khurshid, K.; Qamar, S.R.; Nicolaou, S.; Khosa, F. Gender Disparity in Chest Radiology in North America. Curr. Probl. Diagn. Radiol. 2021, 50, 18-22. [CrossRef]

105. Owen, J.B.; Chan, W.C.; Sunshine, J.H.; Shaffer, K.A. The sex ratio of American radiologists: Comparison and implications by age, subspecialty, and type of practice. AJR Am. J. Roentgenol. 1995, 165, 1337-1341. [CrossRef]

106. Piltch-Loeb, R.; Rosenkrantz, A.B.; Merdjanoff, A.A. Identifying Barriers and Facilitators of Success for Female Radiology Researchers: An Analysis of In-Depth Interviews with Nationally Recognized Leaders of the Field. AJR Am. J. Roentgenol. 2020, 17, 1344-1351. [CrossRef] [PubMed]

107. Piper, C.L.; Scheel, J.R.; Lee, C.I.; Forman, H.P. Gender Trends in Radiology Authorship: A 35-Year Analysis. AJR Am. J. Roentgenol. 2016, 206, 3-7. [CrossRef]

108. Piper, C.L.; Scheel, J.R.; Lee, C.I.; Forman, H.P. Representation of Women on Radiology Journal Editorial Boards: A 40-Year Analysis. Acad. Radiol. 2018, 25, 1640-1645. [CrossRef]

109. Pyatigorskaya, N.; Di Marco, L. Women authorship in radiology research in France: An analysis of the last three decades. Diagn. Interv. Imaging 2017, 98, 769-773. [CrossRef]

110. Pyatigorskaya, N.; Madson, M.; Di Marco, L. Women's career choices in radiology in France. Diagnos. Int. Imaging 2017, 98, 775-783. [CrossRef]

111. Qamar, S.R.; Khurshid, K.; Jalal, S.; McInnes, M.; Probyn, L.; Finlay, K.; Hague, C.J.; Hibbert, R.M.; Joshi, M.; Rybicki, F.J.; et al. Gender Disparity Among Leaders of Canadian Academic Radiology Departments. AJR Am. J. Roentgenol. 2020, 214, 3-9. [CrossRef]

112. Qamar, S.R.; Khurshid, K.; Jalal, S.; Bancroft, L.; Munk, P.L.; Nicolaou, S.; Khosa, F. Academic musculoskeletal radiology: Influences for gender disparity. Skelet. Radiol. 2018, 47, 381-387. [CrossRef] [PubMed]

113. Rosenkrantz, A.; Kotsenas, A.; Duszak, R. Geographic Variation in Gender Disparities in the US Radiologist Workforce. J. Am. Coll. Radiol. 2018, 15, 1073-1079. [CrossRef] [PubMed] 
114. Rosenkrantz, A.B.; Englander, M.J.; Deipolyi, A.R.; Findeiss, L.; Duszak, R., Jr. Clinical Practice Patterns of Interventional Radiologists by Gender. AJR Am. J. Roentgenol. 2019, 213, 867-874. [CrossRef] [PubMed]

115. Roubidoux, M.A.; Packer, M.M.; Applegate, K.E.; Aben, G. Female medical students' interest in radiology careers. J. Am. Coll. Radiol. 2009, 6, 246-253. [CrossRef] [PubMed]

116. Sadigh, G.; Duszak, R., Jr.; Macura, K.J.; Rosenkrantz, A.B. Gender Differences in Modality Interpretation Among Radiologists: An Exploratory Study of Occupational Horizontal Segregation. Acad. Radiol. 2019, 27, 710-714. [CrossRef]

117. Shah, A.; Braga, L.; Braga-Baiak, A.; Jacobs, D.O.; Pietrobon, R. The association of departmental leadership gender with that of faculty and residents in radiology. Acad. Radiol. 2007, 14, 998-1003. [CrossRef]

118. Vernuccio, F.; Arzanauskaite, M.; Turk, S.; Torres, E.T.; Choa, J.; Udare, A.S.; Haroun, D.; Serra, M.M.; Shelmerdine, S.; Bold, B.; et al. Gender discrepancy in research activities during radiology residency. Insights Imaging 2019, 10, 125. [CrossRef]

119. Vydareny, K.H.; Waldrop, S.M.; Jackson, V.P.; Manaster, B.J.; Nazarian, G.K.; Reich, C.A.; Ruzal-Shapiro, C.B. Career advancement of men and women in academic radiology: Is the playing field level? Acad. Radiol. 2000, 7, 493-501. [CrossRef]

120. Wah, T.M.; Belli, A.M. The Interventional Radiology (IR) Gender Gap: A Prospective Online Survey by the Cardiovascular and Interventional Radiological Society of Europe (CIRSE). Cardiovasc. Interv. Radiol. 2018, 41, 1241-1253. [CrossRef]

121. Wang, J.; Khurshid, K.; Jalal, S.; Nicolaou, S.; White, S.B.; Englander, M.J.; Salazar, G.M.; Khosa, F. Influence of Academic Productivity on Gender Disparity in Academic Interventional Radiology. AJR Am. J. Roentgenol. 2019, 212, 1-7. [CrossRef] [PubMed]

122. West, D.L.; Nguyen, H. Ethnic and Gender Diversity in Radiology Fellowships. J. Racial. Ethn Health Disparities 2017, 4, 432-445. [CrossRef]

123. Whitley, N.O.; Evens, R.G.; Moody, M.A.; Putman, C.E.; Sackett, J.F.; Vydareny, K.H. Advancement of women in academic radiology. Investig. Radiol. 1987, 22, 431-435. [CrossRef] [PubMed]

124. Xiao, N.; Oliveira, D.; Gupta, R. Characterizing the Impact of Women in Academic IR: A 12-Year Analysis. J. Vasc. Int. Radiol. 2018, 29, 1553-1557. [CrossRef]

125. Yun, E.J.; Yoon, D.Y.; Kim, B.; Moon, J.Y.; Yoon, S.J.; Hong, S.J.; Baek, S. Closing the Gender Gap: Increased Female Authorship in AJR and Radiology. AJR Am. J. Roentgenol. 2015, 205, 237-241. [CrossRef]

126. Zener, R.; Lee, S.Y.; Visscher, K.L.; Ricketts, M.; Speer, S.; Wiseman, D. Women in Radiology: Exploring the Gender Disparity. J. Am. Coll. Radiol. 2016, 13, 344-350.e1. [CrossRef] [PubMed]

127. Zulfiqar, M.; Khurshid, K.; Moreno, C.C.; Jalal, S.; Nayab, A.; Chang, S.D.; Khara, S.S.; Khosa, F. Examining Gender Disparity in Academic Abdominal Radiology in North America. Curr. Probl. Diagn. Radiol. 2020. [CrossRef]

128. SJR. Scimago Journal \& Country Rank. Available online: https://www.scimagojr.com (accessed on 13 December 2020).

129. Butkus, R.; Serchen, J.; Moyer, D.V.; Bornstein, S.S.; Hingle, S.T.; Health and Public Policy Committee of the American College of Physicians. Achieving Gender Equity in Physician Compensation and Career Advancement: A Position Paper of the American College of Physicians. Ann. Int. Med. 2018, 168, 72-723. [CrossRef] [PubMed]

130. Editorial. Feminism is for everybody. Lancet 2019, 393, 493. [CrossRef]

131. Kubik-Huch, R.A.; Vilgrain, V.; Krestin, G.P.; Reiser, M.F.; Attenberger, U.I.; Muellner, A.U.; Hess, C.P.; Hricak, H. Women in radiology: Gender diversity is not a metric-it is a tool for excellence. Eur. Radiol. 2020, 30, 1644-1652. [CrossRef] [PubMed]

132. Holroyd-Leduc, J.M.; Straus, S.E. \#MeToo and the medical profession. CMAJ 2018, 190, E972-E973. [PubMed]

133. Pattani, R.; Ginsburg, S.; Mascarenhas Johnson, A.; Moore, J.E.; Jassemi, S.; Straus, S.E. Organizational factors contrib uting to incivility at an academic medical center and systemsbased solutions: A qualitative study. Acad. Med. 2018. [CrossRef]

134. Bredella, M.A.; Alvarez, C.; O'Shaughnessy, S.A.; Lavigne, S.D.; Brink, J.A.; Thrall, J.H. Radiology Mentoring Program for Early Career Faculty-Implementation and Outcomes. J. Am. Coll. Radiol. 2020. [CrossRef] [PubMed]

135. Ladd, L.M.; Bonaminio, D.N.; Gonda, A.S.; Gasparis, P.T.; Bell, W.L.; Aaron, V.D.; Heitkamp, D.E. A Mentorship and Networking Group for Women in Radiology. J. Am. Coll. Radiol. 2017, 14, 987-990. [CrossRef] [PubMed]

136. Justice Ruth Bader Ginsburg. A Woman's Voice May do Some Good. Available online: https://www.politico.com/story/2013/0 9/women-oconnor-ginsburg-supreme-court-097313 (accessed on 21 December 2020). 